\title{
EFFECT OF ARGON-ION IRRADIATION ON CAVITY FORMATION AND EVOLUTION IN 18Cr10NiTi AUSTENITIC STEEL
}

\author{
G.D. Tolstolutskaya ${ }^{1}$, S.A. Karpov ${ }^{1}$, A.S. Kalchenko ${ }^{1}$, I.E. Kopanets ${ }^{1}$, A.V. Nikitin ${ }^{1}$, \\ and V.N. Voyevodin ${ }^{1,2}$ \\ ${ }^{1}$ National Science Center “Kharkov Institute of Physics and Technology”, Kharkiv, Ukraine; \\ ${ }^{2}$ V.N. Karazin Kharkiv National University, Kharkiv, Ukraine
}

The swelling behavior of $18 \mathrm{Cr} 10 \mathrm{NiTi}$ austenitic stainless steel irradiated with energetic Ar-ions in the dose range of $40 \ldots 105$ displacements per atom (dpa) with simultaneously implanted argon to the levels of $0.08 \ldots 6.3$ at.\% at temperatures of $550 \ldots 700{ }^{\circ} \mathrm{C}$ was investigated. Transmission electron microscopy (TEM) has been used to study the microstructure evolution and to determine the dependence of swelling on the damage and Ar concentration. It is shown that the highest density and average size of the cavities was observed in the region of the calculated peak damage and Ar concentration. Argon was found to promote cavity swelling at lower temperature. At simultaneous creation of defects and argon implantation it was found a shift of swelling curve to higher temperatures compared to metallic-ion irradiation. The cavity swelling behavior of an austenitic 18Cr10NiTi steel irradiated with energetic argon ions are compared with those resulting from helium implantation.

PACS: 52.40Hf, 28.52Fa, 68.49Sf, 79.20Rf

\section{INTRODUCTION}

The effect of a combination of displacement damage and helium, produced by high energy neutrons, on mechanical properties and dimensional stability of structural materials is one of the key issues in the development of nuclear power. In particular, next generation fast and fusion reactors are estimated to reach extreme doses of displacements per atom (dpa) and transmuting $\mathrm{He}$ [1]. Depending on the neutron spectrum and fluence, helium is produced in materials by transmutation reactions in amounts up to thousands of atomic parts per million (appm). Previous studies have demonstrated that helium plays a strong role in the development of the irradiated microstructure with modifications to cavities, dislocations, and secondary phases.

It is shown that the swelling behavior under ion irradiation is influenced by the mode of helium injection [2]. A study by Farrell et al. [3] examined variation in void behavior between pre-injected, single beam irradiation, and co-injected irradiation of $\mathrm{Fe}-\mathrm{Cr}-\mathrm{Ni}$ alloy. They found that in the dual beam case swelling an order of magnitude more than the pre-implanted irradiation ( $8 \%$ versus $0.3 \ldots 0.7 \%$ ). The resulted void microstructure is also varied between pre injected and dual beam. The voids in the pre-implanted samples were much smaller than those in the dual beam irradiation and also were at a higher concentration.

In [4] it was found that the addition of helium can promote the shift of the peak swelling rate location by $\sim 40 \ldots 70^{\circ} \mathrm{C}$ higher from the temperature with no helium additions. Helium affected void nucleation by decreasing the time to appearance of visible voids. The simultaneous helium injection shifts the temperature of the onset of swelling to the region of low temperatures. Despite a large amount of data, the precise mechanism of helium influence on void nucleation and growth behavior is still not known for candidate structural materials including the austenitic, ferritic and ferriticmartensitic alloys for Gen IV reactors, fusion and accelerator-driven spallation (ADS) devices [5]. Further research needed to solve the fundamental overriding questions about $\mathrm{He}$ and dpa effects and their synergisms.

There are several methodological approaches in the studying of the helium effect on the development of microstructure. In Ref. [6, 7] it was demonstrated that in situ He implantation in mixed spectrum fission reactor irradiations provides a very suitable approach to assessing the effects of He-dpa synergisms. However, because the typical water-cooled test reactors have a low accumulative neutron dose, $1 \ldots 10 \mathrm{dpa} /$ year, the ion irradiation experiments using light and heavy ion beams have been applied as surrogates for reactor irradiation with good success [8, 9]. Ion irradiation provides a possibility to investigate the swelling behavior at higher doses and to determine the void behavior as a function of temperature.

To study the effects of a combination of large levels of helium and displacement damage often use dual ion beam irradiations by means of two accelerators [10, 11]. In contrast, Mazey et al. [12] have established that by a reasonable choice of $\mathrm{e} / \mathrm{m}$ ratio and ion mixture at the ion source, a mixed beam of high energy neon and nickel ions could be produced and used for simulation tests of bubble and void formation and general radiation damage studies. In this case, neon is used as an analogue for helium.

Another approach is to use inert gases $\mathrm{Ne}, \mathrm{Ar}$, and $\mathrm{Kr}$ with a larger atomic mass than helium and this results in greater energy transfer during collisions and thus a larger atomic displacement rate of target atoms [13].

Helium, neon and argon have been compared in terms of cavity nucleation during $1 \mathrm{MeV}$ electron irradiation of a Nimonic PEl6 alloy in HVEM [12]. These results and results for 316 stainless steel [14] have indicated that neon irradiation produces voids with sizes and densities similar to that of helium.

The objective of this paper is to determine the effect of implanted argon on swelling of $18 \mathrm{Cr} 10 \mathrm{NiTi}$ austenitic stainless steel. The focus is on how the resulting cavity influenced by the irradiation variables, including, displacements per atom, Ar concentration and irradiation temperature, as well as comparison the 
swelling behavior with those resulting from helium implantation.

\section{MATERIAL AND METHODS}

Samples of $18 \mathrm{Cr} 10 \mathrm{NiTi}$ austenitic stainless steel for TEM studies were prepared as disks of $3 \mathrm{~mm}$ in diameter. Thin foils were obtained by mechanical thinning of the disks down to $130 \mu \mathrm{m}$ followed by electropolishing and short-term annealing. To remove a specified depth layer of material from irradiated side of the sample the electro-pulse technique was used [15].

Microstructural and swelling data were extracted using conventional techniques conducted on JEM100CX and JEM-2100 transmission electron microscopes (TEM), employing standard bright-field techniques. Analysis of TEM micrographs were performed using image processing software.

The initial pre-irradiation structures of $18 \mathrm{Cr} 10 \mathrm{NiTi}$ steel are shown in Fig. 1.

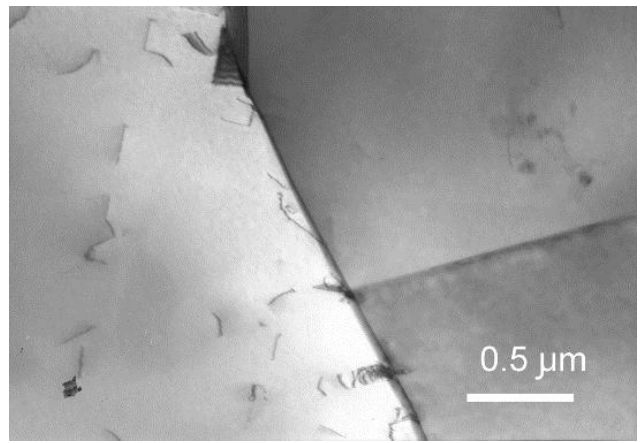

Fig. 1. Initial structure for 18Cr10NiTi steel

Steel 18Cr10NiTi structure after solution annealing contains twins of annealing precipitates of second phase (carbides and titanium carbonitrides) and dislocations.
Majority of perfect dislocation are extended on partial dislocation with stacking fault formation. Sum density of dislocation is $\sim 10^{8} \mathrm{~cm}^{-2}$.

The accelerating-measuring system "ESU-2" with an oil-free pumping system with a residual target-chamber pressure of $\sim 5 \cdot 10^{-5} \mathrm{~Pa}$ was used for the creation of radiation damage [16]. The argon ions with energies of $0.7 \ldots 1.4 \mathrm{MeV}$ were chosen for irradiation experiments in order to investigate the features of swelling at different ratio of damage dose and gas concentration. The implantation temperature varied from 550 to $700{ }^{\circ} \mathrm{C}$ and controlled by combination of resistive and ion beam heating. The error in the temperature measurement did not exceed $\pm 5 \%$. The ion beam current during irradiation was measured directly from the specimen. The error in the beam current and, consequently of the damage dose, did not exceed $\pm 10 \%$.

The damage calculations for argon irradiation were based on the Kinchin-Pease damage energy model, with a displacement energy of $40 \mathrm{eV}$ for $\mathrm{Fe}, \mathrm{Cr}$, and $\mathrm{Ni}$, as recommended in ASTM E521-96 (2009) [17]. The SRIM code [18] was used for calculations of ion projected ranges $\left(R_{p}\right)$ and range straggling $\left(\Delta R_{p}\right)$ to evaluate the concentration of deposited gas atoms. The various measures of damage were derived from the profiles shown in Fig. 2, scaled to the actual Ar and dpa for each data set.

\section{RESULTS AND DISCUSSION}

Calculated depth distribution profile of damage and concentration of $\mathrm{Ar}$ atoms implanted in $18 \mathrm{Cr} 10 \mathrm{NiTi}$ steel to a dose of $1.5 \cdot 10^{17} \mathrm{~cm}^{-2}$ and microstructure evolution with depth are shown in Fig. 2.

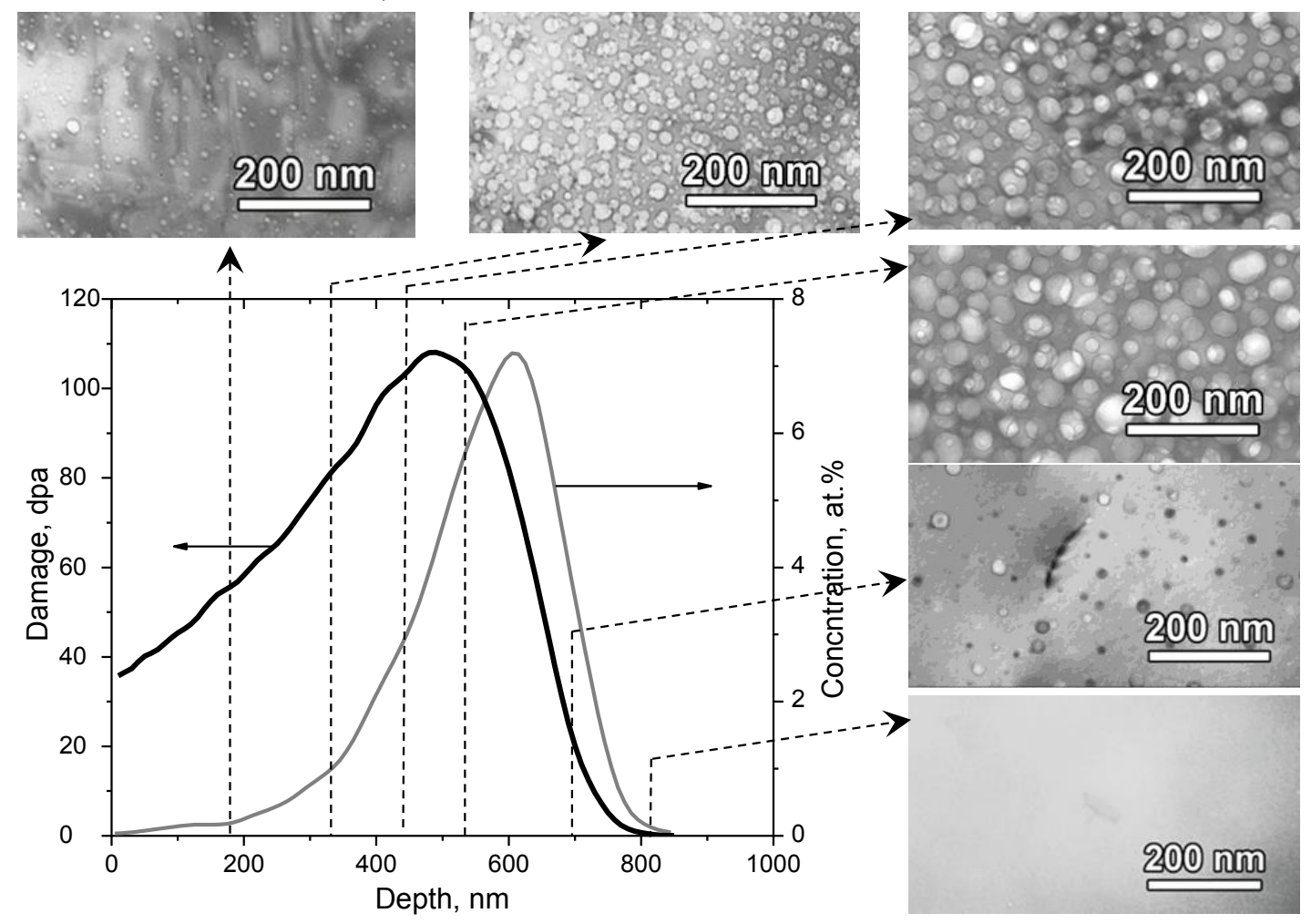

Fig. 2. The depth distribution of damage and concentration of $1.4 \mathrm{MeV}$ Ar ions in 18Cr10NiTi calculated with SRIM. Microstructure of steel at specified depth after irradiation at $550{ }^{\circ} \mathrm{C}$ 
Irradiation cause damage production at the level from 40 to $105 \mathrm{dpa}$ with simultaneously implanted argon in the range of $0.08 \ldots 6.3$ at.\%. TEM studies showed that irradiation with argon at $550{ }^{\circ} \mathrm{C}$ is accompanied by the creation of cavity type defects. The higher dpa and Ar clearly lead to increased cavity size, primarily due to the presence of more numerous and larger faceted cavities (see Fig. 2).

In the case of $18 \mathrm{Cr} 10 \mathrm{NiTi}$ irradiation with metallic ions (without gas co-injection) to the dose of $50 \mathrm{dpa}$ at a damage rate of $10^{-2} \mathrm{dpa} / \mathrm{s}$, the swelling was observed in the temperature range $590 \ldots 640{ }^{\circ} \mathrm{C}$ [19]. At lower temperatures, high sink concentration and low effective vacancy diffusion coefficient reduce the vacancies supersaturation and, therefore, inhibit the formation and growth of cavities [8]. However, the simultaneous introduction of vacancies and argon leads to the development of porosity even at $550{ }^{\circ} \mathrm{C}$.

The changes of cavities number density $(\mathrm{N})$ and average cavity size $\langle d\rangle$ as a function of depth are plotted in Fig. 3 in $100 \mathrm{~nm}$ sections from 0 to $800 \mathrm{~nm}$. The removing of $\sim 100 \mathrm{~nm}$ depth-layer of material was performed by the electro-pulse technique.

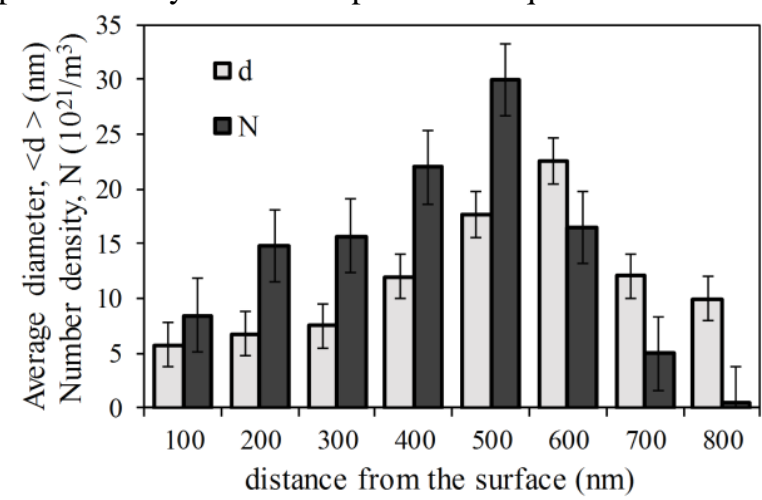

Fig. 3. Average size (d) and number density of cavities

(N) as a function of depth for $1.4 \mathrm{MeV}$ Ar ion irradiation at $550{ }^{\circ} \mathrm{C}$ to $1.5 \cdot 10^{17} \mathrm{~cm}^{-2}$

The number density and average diameter of voids as well as swelling tended to increase with increasing of damage level and argon concentration to a depth of 500 nm (see Figs. 3, 4).

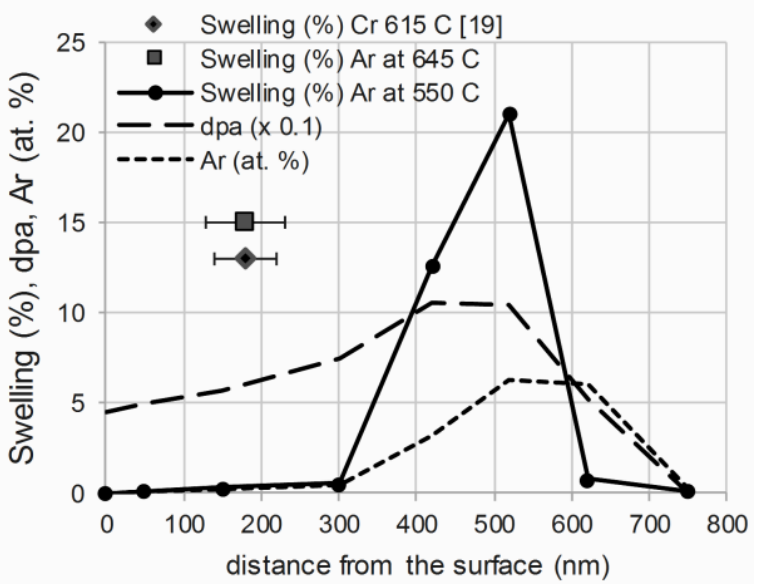

Fig. 4. The depth distribution of calculated damage (dpa), gas concentration (at.\%) and swelling (\%) for 1.4 MeV Ar ion irradiations at $550{ }^{\circ} \mathrm{C}$ to $1.5 \cdot 10^{17} \mathrm{~cm}^{-2}$.

The value of damage is reduced by an order of magnitude for better perception
More detailed analysis shows that at depths less than $300 \mathrm{~nm}$, i.e. in conditions of low gas concentration and high dpa, the size of the cavities virtually does not grow. Only their density increases, indicating the cavities nucleation process. This observation demonstrates that irradiation of austenitic steel with argon ions has the similar effects as helium irradiation [2]. The temperature shift of swelling to the region of lower temperatures is due to argon-associated stabilization of very small vacancy clusters, which have a very short lifetime without such stabilization (the same as in helium case). As a result, a high density of small cavities is formed. This effect depends on the irradiation temperature. At a temperature of $550{ }^{\circ} \mathrm{C}$, the mobility of vacancies is not enough for the growth of large cavities. The swelling in this case is about $0.1 \%$ (see Fig. 4). However, at irradiation temperature of $645^{\circ} \mathrm{C}$, everything else being equal, the swelling is $(15 \pm 3) \%$ and virtually coincides with the swelling upon irradiation with metallic ions, which is $(13 \pm 2) \%$ (see Fig. 4).

It is seen from Fig. 2 that as the defect density and argon concentration increases, the swelling increases even at $550{ }^{\circ} \mathrm{C}$, reaching more than $20 \%$ at a depth of $\sim 500 \mathrm{~nm}$, which is a manifestation of the joint effect of a large number of defects and argon concentration. Fig. 4 shows a decrease in void swelling at depths greater than $500 \mathrm{~nm}$ due mostly to a decrease in void number density, with more little effect of diameter.

One of the primary questions about $\mathrm{He}$ and dpa effects and their synergisms is He/dpa ratio which varies substantially for different nuclear facilities and estimates to be $<1$ for fast fission, $\approx 10$ for fusion, and up to 100 for spallation proton-neutron [2]. Recently, this question has been studied in detail for ferritic steels $[20,21]$, and it has been shown that helium reduces the swelling as the He/dpa ratio increases. It is interesting to determine the effect of $\mathrm{Ar} / \mathrm{dpa}$ ratio on the swelling behavior of $18 \mathrm{Cr} 10 \mathrm{NiT}$ austenitic steel.

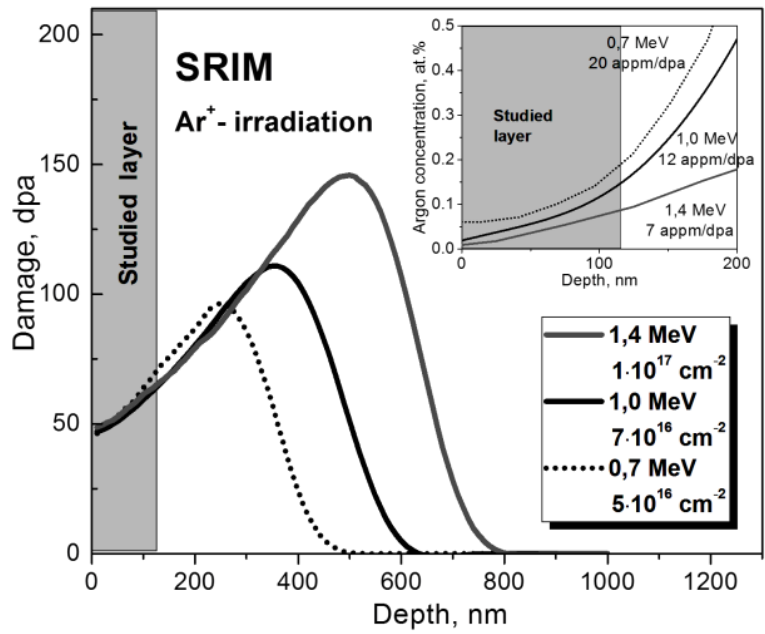

Fig. 5. The depth distributions of damage

in 18Cr10NiTi steel calculated with SRIM for the case of different $\mathrm{Ar}^{+}$ion energies. Corresponding $\mathrm{Ar}$ concentration profiles are shown in the insert

In order to simulate irradiation conditions that encompass a wide range of $\mathrm{Ar} / \mathrm{dpa}$, three irradiations were performed with $\mathrm{Ar}^{+}$energies of $0.7,1.0$, and 
1.4 MeV. One nominal damage level of $60 \mathrm{dpa}$ at a reference point $100 \mathrm{~nm}$ from the specimen surface was obtained. Fig. 5 shows calculated depth profiles of the dpa damage corresponding to specified ion energies. Argon deposition profiles in the depth range of interest are shown in the inset of Fig. 5. Such an approach yielded average values of 7, 12 and $20 \mathrm{appm} / \mathrm{dpa}$ in the near-surface region for $1.4,1.0$, and $0.7 \mathrm{MeV} \mathrm{Ar}^{+}$ irradiation, respectively. Fig. 6 shows resulted cavities microstructure formed after irradiation of $18 \mathrm{Cr} 10 \mathrm{NiTi}$ under considered conditions at temperatures of 600 , 625 , and $645^{\circ} \mathrm{C}$.

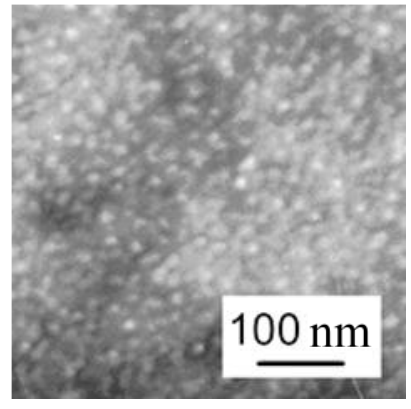

$a$

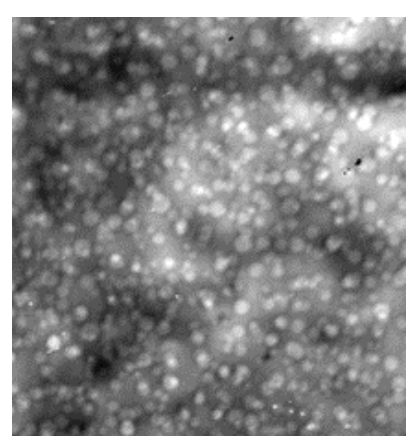

$d$

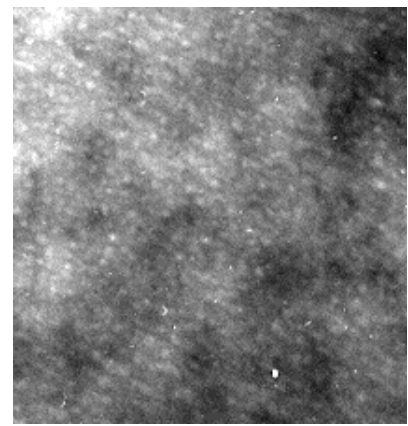

$g$

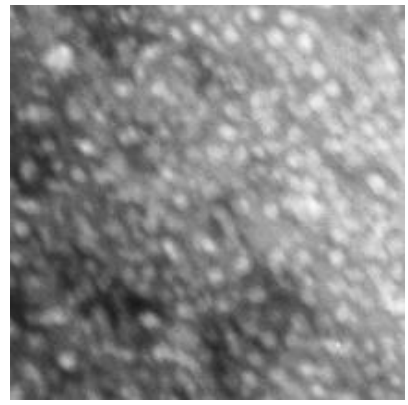

$b$
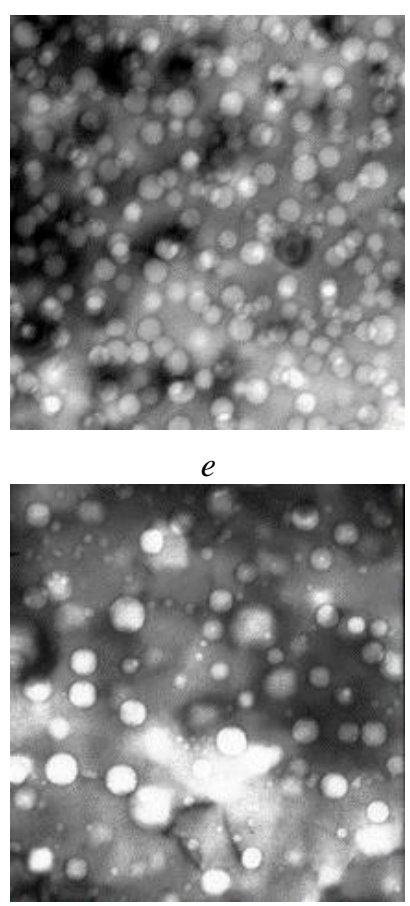

$h$

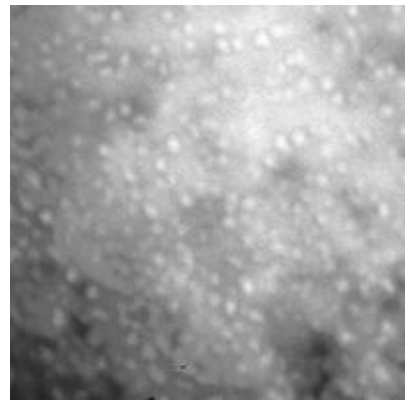

C
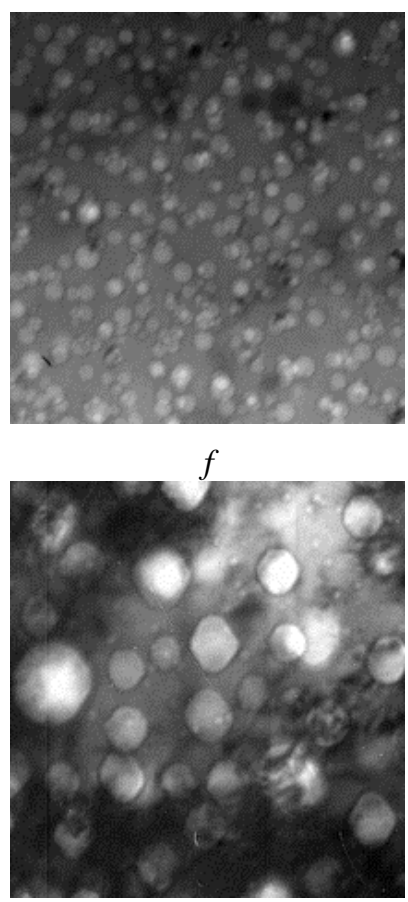

Fig. 6. Microstructure of $18 \mathrm{Cr} 10 \mathrm{NiTi}$ steel irradiated with argon ions to a nominal dose of 60 dpa $\approx$ at temperatures of $600(a, d, g), 625(b, e, h)$ and $645^{\circ} \mathrm{C}(c, f, i)$ and Ar/dpa ratio of $20(a, b, c), 12(d, e, f)$ and $7(g, h, i)$

Cavities microstructure was analyzed in the near surface region $(0 \ldots 120 \mathrm{~nm})$. Table summarizes the irradiation conditions, and corresponding variations of cavities number density $\mathrm{N}$, average diameter $\langle\mathrm{d}\rangle$, as well as the value of swelling (s) for each investigated case.

Cavity parameters and swelling with variables Ar/dpa

\begin{tabular}{|c|c|c|c|c|}
\hline $\begin{array}{c}\text { Ar/dpa, } \\
\text { appm/dpa }\end{array}$ & $\begin{array}{c}\mathrm{T}_{\text {irr }}, \\
\mathrm{C}\end{array}$ & $\begin{array}{c}<\mathrm{d}>, \\
\mathrm{nm}\end{array}$ & $\begin{array}{c}\mathrm{N}, \\
\times 10^{22} \mathrm{~cm}^{-3}\end{array}$ & $\begin{array}{c}\mathrm{s}, \\
\%\end{array}$ \\
\hline 20 & 600 & 9,9 & 1,44 & 0,82 \\
\hline & 625 & 11,1 & 1,52 & 1,15 \\
\hline & 645 & 9,6 & 1,32 & 0,63 \\
\hline 12 & 600 & 11,7 & 1,68 & 1.5 \\
\hline & 625 & 28,3 & 0,42 & 5,1 \\
\hline & 645 & 23,1 & 0,49 & 3,9 \\
\hline 7 & 600 & 9,1 & 1,96 & 0,8 \\
\hline & 625 & $9,5 / 35$ & 0,39 & 7,6 \\
\hline & 645 & $10,3 / 75$ & 0,11 & 10,2 \\
\hline
\end{tabular}

As follows from the Table, the maximum cavity size at a ratio of 20 and 12 appm Ar/dpa is observed at $625^{\circ} \mathrm{C}$. The cavities number density in the first case virtually constant, while for 12 appm/dpa considerable drop of density with temperature is observed. The maximum swelling rate is located at the temperature of $625^{\circ} \mathrm{C}$, which is $10{ }^{\circ} \mathrm{C}$ higher compared to irradiation with metallic ions only.

At a ratio of 7 appm Ar/dpa the evolution of microstructure is more complicated. At lowest irradiation temperature of $600{ }^{\circ} \mathrm{C}$ the high-density voids with average diameter of $9.1 \mathrm{~nm}$ are formed. This result is very similar to that of previous two cases. However, at irradiation temperatures of 625 and $645^{\circ} \mathrm{C}$ the situation is dramatically different (Fig. 7). Along with small pores, voids with an average diameter of $35 \mathrm{~nm}$ are formed at irradiation temperature of $625^{\circ} \mathrm{C}$, thereby forming a bimodal distribution. Argon irradiation at 
$645^{\circ} \mathrm{C}$ produced a low-density of non-uniformly distributed cavities with bimodal sizes ranging from $10 \mathrm{~nm}$ pores to $75 \mathrm{~nm}$ faceted voids (see Fig. 7,c). In the latter case, the value of swelling exceeds $15 \%$.

Synchronous presence of a considerable number of small and big cavities indicates that there are going both growth and still being nucleation of cavities. Nevertheless, under these conditions, the swelling is determined by large vacancy cavities.

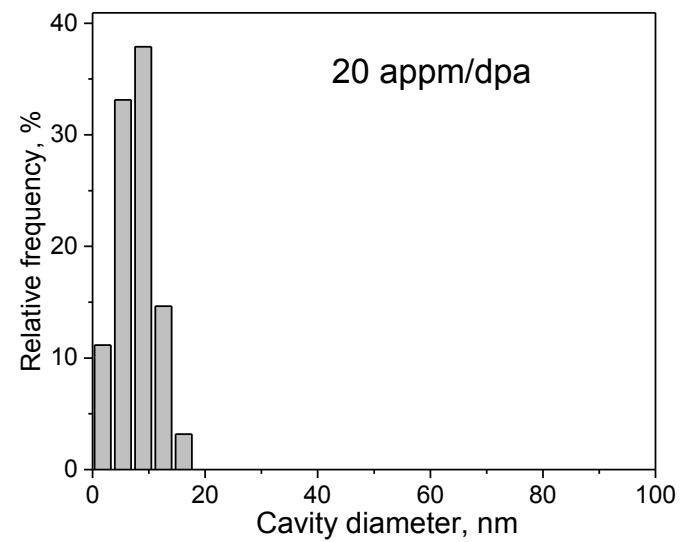

$a$

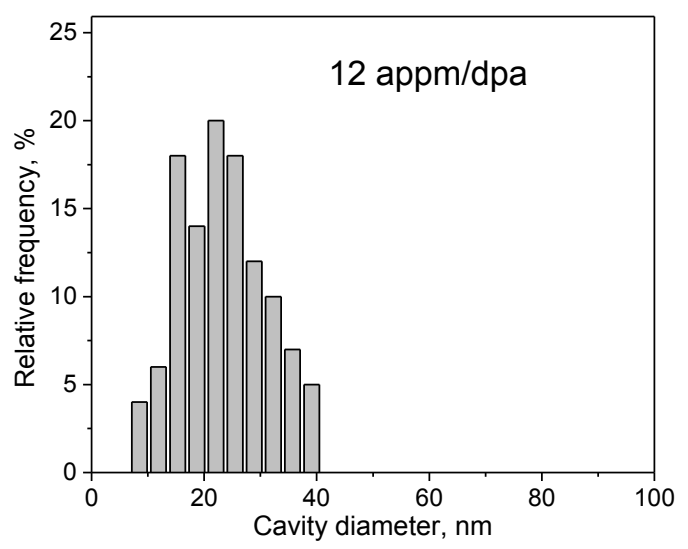

b

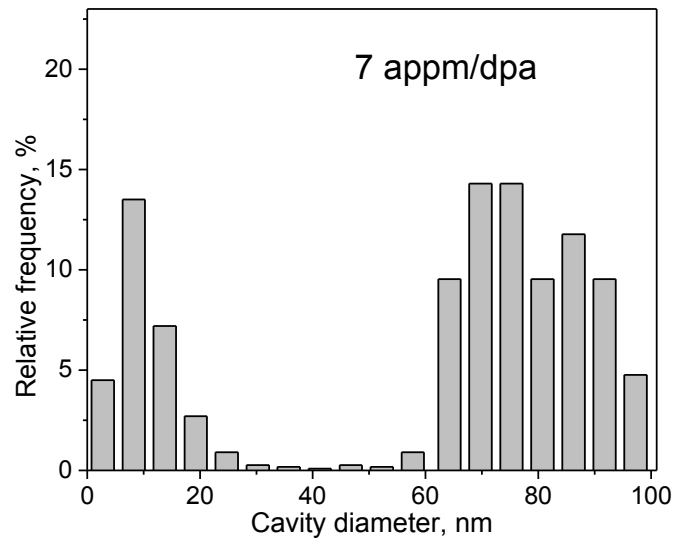

$c$

Fig. 7. Cavity distributions in steel irradiated to $60 \mathrm{dpa}$ at $645^{\circ} \mathrm{C}$ in the $0 \ldots 120 \mathrm{~nm}$ region for different appm Ar/dpa ratio

The data presented demonstrate that argon as well as helium inhibits the swelling as the appm/dpa ratio grows.

It is considered that argon migrates through the solid due to enhanced vacancy diffusion, while helium migrates mainly by interstitial diffusion. This difference leads to completely different nucleation densities and has a significant effect on the total void swelling. But trends, as shown by the present results, can persist. Therefore, investigation of different materials under the same irradiation conditions with high-energy argon ions makes it possible to rank their tolerance to irradiation.

\section{CONCLUSION}

This paper shows the changes in microstructure and swelling of austenitic $18 \mathrm{Cr} 10 \mathrm{NiTi}$ after $0.7 \ldots 1.4 \mathrm{MeV}$ $\mathrm{Ar}^{+}$irradiations in the temperature range of $550 \ldots 700^{\circ} \mathrm{C}$ to doses between of 40 and 105 dpa with simultaneously implanted argon levels of $0.08 \ldots 6.3$ at.\% at nominal $\mathrm{Ar} / \mathrm{dpa}$ ratios of 7 and $20 \mathrm{appm} / \mathrm{dpa}$ and provides the following conclusions:

Irradiated microstructure strongly depends on $\mathrm{Ar}$ concentration, implantation temperature and level of displacements per atom.

At temperatures below $600{ }^{\circ} \mathrm{C}$ the swelling is suppressed despite the growth of damage until the argon concentration reaches value $\sim 0.5$ at. $\%$.

At a dose of 60 dpa the addition of argon shifted the peak swelling rate location by $\sim 10 \ldots 30^{\circ} \mathrm{C}$ higher from $615^{\circ} \mathrm{C}$ with no argon additions.

Argon as well as helium shifts the temperature of the onset of swelling to the region of low temperatures and inhibits the swelling as the appm/dpa ratio grows.

The results indicate that argon can be used as an analogue for helium in implantation-and-annealing experiments, provided that the doses are adjusted so that the gas concentrations are equivalent.

\section{REFERENCES}

1. S.J. Zinkle, J.T. Busby. Structural materials for fission \& fusion energy // Mater. Today. 2009, v. 12, N 11, p. 12-19.

2. Y. Dai, G.R. Odette, T. Yamamoto, The effects of helium on irradiated structural alloys / R. Konings, T.R. Allen, R.E. Stoller, S. Yamanaka (Eds.). Comprehensive Nuclear Materials. Elsevier, 2012, p. 142-193.

3. K. Farrell, M.B. Lewis, N. Packan. Simultaneous bombardment with helium, hydrogen, and heavy ions to simulate microstructural damage from fission or fusion neutrons // Scr. Metall. 1978, v. 12, p. 1121-1124.

4. N.H. Farrell, N.H. Packan. A helium-induced shift in the temperature dependence of swelling // $\mathrm{J}$. Nucl. Mater. 1979, v. 86, p. 683-693.

5. F.A. Garner. Radiation damage in austenitic steels / R. Konings, T.R. Allen, R.E. Stoller, S. Yamanaka (Ed.). Comprehensive Nuclear Materials, v. 4. Elsevier, 2012, p. 33-95.

6. G.R. Odette, P. Miao, D.J. Edwards, R.J. Kurtz. Helium effects on microstructural evolution in tempered martensitic steels: In situ helium implanter studies in HFIR // J. Nucl. Mater. 2009, v. 386-388, p. 338-341.

7. T. Yamamoto, G.R. Odette, P. Miao, et al. The transport and fate of helium in nanostructured ferritic alloys at fusion relevant He/dpa ratios and dpa rates // $J$. Nucl. Mater. 2007, v. 399, p. 367-370.

8. В.Н. Воеводин, И.М. Неклюдов. Эволюичия структурно-фазового состояния и радиационная стойкость конструкиионных материалов. Киев: Наукова думка, 2006, 376 с. 
9. G.S. Was, Z. Jiao, E. Getto, et al. Emulation of reactor irradiation damage using ion beams // Scripta Materialia. 2014, v. 88, p. 33-36.

10. E.H. Lee, J.D. Hunn, T.S. Byun, L.K. Mansur. Effects of helium on radiation-induced defect microstructure in austenitic stainless steel // J. Nucl. Mater. 2000, v. 280, p. 18-24.

11. H. Kishimoto, K. Yutani, R. Kasada, A. Kimura. Helium cavity formation research on oxide dispersed strengthening (ODS) ferritic steels utilizing dual-ion irradiation facility // Fus. Eng. Des. 2006, v. 81, p. $1045-1049$.

12. D.J. Mazey, B.C. Sowden, E.J. Jones. Mixed $\mathrm{Ne} / \mathrm{Ni}$ beams for radiation damage studies on the Harwell variable energy cyclotron // Nuclear Instruments and Methods in Physics Research B. 1985, v. 12 , p. 419-425.

13. N. Marochov and P.J. Goodhew. A comparison of the growth of helium and neon bubbles in nickel // $J$. Nucl. Mater. 1988, v. 158, p. 81-86.

14. N. Marochov and P.J. Goodhew. Neon bubbles in 316 stainless steel // Radiat. Eff. Lett. 1984, v. 85, p. 61-65.

15. M.B. Toloczko, F.A. Garner, V.N. Voyevodin et al. Ion-induced swelling of ODS ferritic alloy MA957 tubing to 500 dpa // J. Nucl. Mater. 2014, v. 453, p. 323-333.

16. G.D. Tolstolutskaya, V.V. Ruzhytskiy, I.E. Kopanetz, V.N. Voyevodin, A.V. Nikitin, S.A. Karpov, A.A. Makienko, T.M. Slusarenko. Accelerating complex for study of helium and hydrogen behavior in conditions of radiation defects generation // Problems of Atomic Science and Technology. Series "Physics of Radiation Effect and Radiation Materials Science”. 2010, N 1, p. 135-140.

17. ASTM E521-96, 2009, ASTM.

18. http://www.srim.org/

19. O.V. Borodin, V.V. Bryk, A.S. Kalchenko, et al. Synergistic effects of helium and hydrogen on selfion-induced swelling of austenitic 18Cr10NiTi stainless steel // J. Nucl. Mater. 2013, v. 442, p. S817-S820.

20. T. Yamamoto, Y. Wu, G. R. Odette, et al. A dual ion irradiation study of helium-dpa interactions on cavity evolution in tempered martensitic steels and nanostructured ferritic alloys // J. Nucl. Mater. 2014, v. 449, p. 190-199.

21. E. Getto, Z. Jiao, A.M. Monterrosa, K. Sun, G.S. Was. Effect of pre-implanted helium on void swelling evolution in self-ion irradiated HT9 // J. Nucl. Mater. 2015, v. 462, p. 458-469.

Article received 05.03.2020

\title{
ВЛИЯНИЕ ОБЛУЧЕНИЯ ИОНАМИ АРГОНА НА ОБРАЗОВАНИЕ И РАЗВИТИЕ ПОРИСТОСТИ В АУСТЕНИТНОЙ СТАЛИ Х18Н10Т
}

\author{
Г.Д. Толстолуцкая, С.А. Карпов, А.С. Кальченко, И.Е. Копанец, А.В. Никитин, В.Н. Воеводин
}

Исследовано поведение распухания аустенитной нержавеющей стали $18 \mathrm{Cr} 10 \mathrm{NiTi}$, облученной энергетичными ионами $\mathrm{Ar}$ в диапазоне доз 40...105 смещений на атом (сна) при одновременной имплантации аргона до уровней $0,08 \ldots 6,3$ ат.\% при температуре $550 \ldots 700{ }^{\circ} \mathrm{C}$. Просвечивающая электронная микроскопия (ПЭМ) была использована для изучения эволюции микроструктуры и определения зависимости распухания от дозы и концентрации Ar. Показано, что наибольшая плотность и размер полостей наблюдаются в области расчетного пика дефектов и концентрации Ar. Было обнаружено, что аргон способствует распуханию при более низкой температуре. При одновременном создании дефектов и имплантации аргона было обнаружено смещение кривой распухания в сторону более высоких температур по сравнению с облучением ионами металлов. Поведение распухания аустенитной стали $18 \mathrm{Cr} 10 \mathrm{NiTi}$, облученной энергетичными ионами аргона, сравнивается с таковым в случае имплантации гелия.

\section{ВПЛИВ ОПРОМІНЕННЯ ІОНАМИ АРГОНУ НА УТВОРЕННЯ І РОЗВИТОК ПОРИСТОСТІ В АУСТЕНІТНІЙ СТАЛІ Х18Н10Т}

\section{Г.Д. Толстолуцька, С.О. Карпов, О.С. Кальченко, І.С. Копанець, А.В. Нікітін, В.М. Воєводін}

Досліджено поведінку розпухання аустенітної нержавіючої сталі 18Cr10NiTi, опроміненої енергетичними іонами Ar в діапазоні доз 40...105 зсувів на атом (зна) при одночасній імплантації аргону до рівнів 0,08...6,3 ат.\% при температурі 550..700 ${ }^{\circ} \mathrm{C}$. Просвічувальна електронна мікроскопія (ПЕМ) була використана для вивчення еволюції мікроструктури та визначення залежності розпухання від дози i концентрації Ar. Показано, що найбільша щільність і розмір порожнин спостерігаються в області розрахункового піку дефектів і концентрації Ar. Було виявлено, що аргон сприяє розпуханню при більш низькій температурі. При одночасному створенні дефектів і імплантації аргону було виявлено зсув кривої розпухання в сторону більш високих температур у порівнянні з опроміненням іонами металів. Поведінка розпухання аустенітної сталі $18 \mathrm{Cr} 10 \mathrm{NiTi}$, опроміненої енергетичними іонами аргону, порівнюється 3 такою у разі імплантації гелію. 